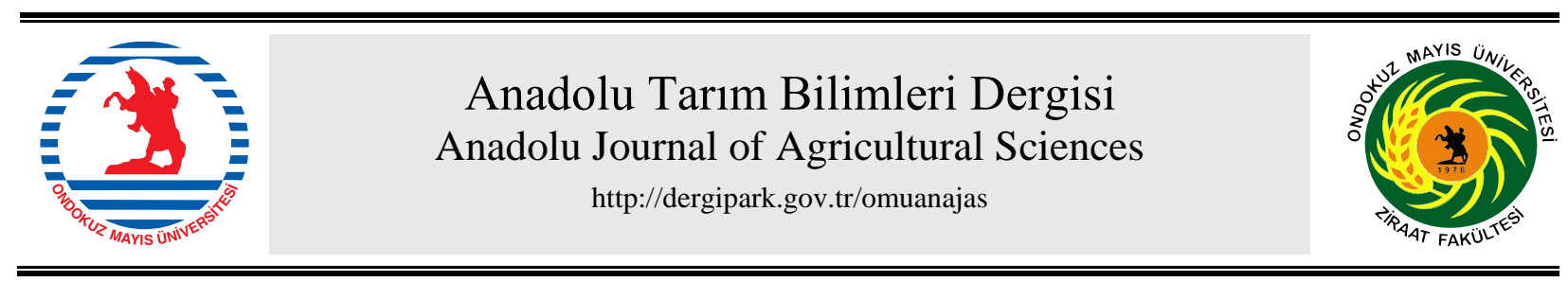

Araştırma/Research

Anadolu Tarım Bilim. Derg./Anadolu J Agr Sci, 36 (2021)

ISSN: 1308-8750 (Print) 1308-8769 (Online)

doi: 10.7161/omuanajas.723104

\title{
İspir Kuru Fasulye (Phaseolus vulgaris L.) Popülasyonunun Karakterizasyonu ve Seleksiyon Yoluyla Islahı
}

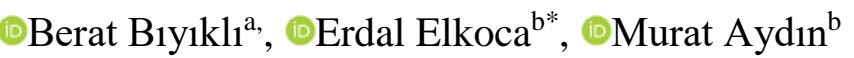 \\ ${ }^{a}$ Atatürk Üniversitesi, Ziraat Fakültesi, Tarla Bitkileri Bölümü, Erzurum, Türkiye \\ ${ }^{b}$ Ağrı İbrahim Çeçen Üniversitesi, Meslek Yüksek Okulu, Bitkisel ve Hayvansal Üretim Bölümü, Ağrl, Türkiye \\ ${ }^{c}$ Atatürk Üniversitesi, Ziraat Fakültesi, Tarımsal Biyoteknoloji Bölümü, Erzurum, Türkiye
}

*Sorumlu yazar/corresponding author: eelkoca@agri.edu.tr

Geliş/Received 21/04/2020 Kabul/Accepted 01/12/2020

\begin{abstract}
ÖZET
Erzurum'un İspir ilçesinde üretilen şeker tane tipindeki kuru fasulye, lezzetli oluşu ile ülke çapında tanınmakta ve talep edilmektedir. Ancak, ilçede yetiştirilen popülasyonun saf olmayışı yetiştiricilik, pazarlama, kullanım ve tüketiminde çeşitli sorunlara neden olmakta ve ilçede yetiştirilen popülasyon içerisinden popülasyonu en iyi şekilde temsil edebilen saf hatların belirlenmesine ihtiyaç duyulmaktadır. Buradan hareketle, bu çalışma bölgeye has materyalden a) tek bitki seleksiyonu yöntemiyle saf hatların elde edilmesi ve tanımlamalarının (karakterizasyon) yapılması, b) saf hatlar arasından, ileriki çalışmalarda tescil ettirilmek üzere, seleksiyon 1slahı yöntemiyle üstün özellikli olanların belirlenmesi amacıyla yürütülmüştür. İlçede kuru fasulye yetiştiriciliği yapılan köylerden hasat döneminde tek bitki seleksiyonuyla seçilen 40 adet saf hat araştırmamızın materyalini oluşturmuştur. Hatlar, Elkoca-05 çeşidi ile birlikte 2014 yılında tesadüf blokları deneme deseninde 3 tekrarlamalı olarak Erzurum Merkez'deki deneme istasyonunda morfolojik karakterizasyon, seleksiyon ve verim denemelerine alınmışlardır. Hatların karakterizasyonunda IPGRI ve EU-CPVO tarafından geliştirilen çeşit değerlendirme kriterleri esas alınmıştır. Ayrıca, çıkıştan hasada kadarki dönemde, fenoloji, verim ve verim unsurları ile ilgili gözlem ve ölçümler yapılmıştır. Böylece hatların değerlendirilmesinde, 14 tanesi kantitatif ve 28 tanesi ise kalitatif olmak üzere toplam 42 adet özellik dikkate alınmıştır. Morfolojik karakterizasyon çalışmaları sonucunda yaprak, çiçek ve tohum özellikleri bakımından hatlar arasında farkların bulunduğu; hatların büyüme şekli ve bakla özellikleri bakımından ise benzer olduğu belirlenmiştir. Verim ve verim unsurları bakımından da hatlar arasında önemli farkların bulunduğu saptanmıştır. Hatlar 42 adet kalitatif ve kantitatif özellik bakımından kümeleme analizine tabi tutulmuş ve hatların 5 grup altında kümelendiği belirlenmiştir. Çalışma sonunda, tane verimi standart çeşitten yüksek olan 15 hat ile seleksiyon çalışmalarına devam edilmesine karar erilmiştir.
\end{abstract}

\section{Characterization and selection of İspir dry bean (Phaesolus vulgaris L.) population}

\section{ABSTRACT}

Dry beans are the most important crop grown in İspir district of Erzurum. There is considerable variation within bean population in the area with white circular seed types much on demand in the market. But, mixed populations limit production, marketing and use of beans in the area. This work is carried out in order to solve current problem by collecting, evaluating and selecting best representative pure lines for a possible future cultivar development. Forty pure lines were selected from İspir district at harvest stage. Lines, along with standard dry bean cultivar Elkoca-05, were subjected to characterization, selection and yield trials. The experiment was arranged in randomized block design with three replicates in 2014 growing season on the experimental field of Ataturk University, Erzurum. Description of the lines was performed according to morphologic description criteria developed by
Anahtar Sözcükler: Fasulye Tanımlama Seleksiyon Kümeleme analizi

Keywords: Bean Characterization Selection Cluster analysis 
IPGRI and EU-CPVO. Phenology, yield and yield components were also investigated in the period between emergence and harvest. Thereby, total 42 characteristics (14 quantitative and 28 qualitative) were considered for characterization of the lines. Morphological characterization trials indicated that there were differences among lines in terms of leaf, flower and seed characteristics, while lines had similar growth habit and pod features. Yield and yield components also showed significant differences among lines. To determine the morphologic variability, lines were subjected to cluster analysis in terms of 42 quantitative and qualitative characteristics. Cluster analyses revealed that lines classified into 5 groups. At the end of the experiment, 15 lines having higher seed yield than standard cultivar were selected for future studies.

\section{Giriş}

Ülkeye giren yeni çeşitler üretim miktarına olumlu katkı sağlamakla birlikte, yerel köy çeşitlerinin daha az kullanımına neden olabilmekte ve hatta zaman içerisinde yerel çeşitlerin yok olması gibi olumsuzlukları da beraberinde getirebilmektedirler. Oysa yerel köy çeşitleri gelecekteki araştırmalarda başvurulacak, bazı konulardaki potansiyelleri henüz aydınlatılmamış eşsiz gen kaynaklarıdır.

Ülkemizin bazı bölgelerinde, coğrafi nedenler gibi etmenler, bitkisel üretimin daha çok aile ihtiyacı veya yöresel pazarlara yönelik, girdinin az ve çeşidin yerel olduğu geleneksel tarım olarak nitelendirebileceğimiz tarzda sürmesini gerekli kılmaktadır. Bu alanlar damak tadımıza daha uygun ve lezzetli yerel materyalleri bulunduran birer hazine niteliğindedir.

Erzurum’un İspir ilçesinin tarımsal yapısı incelendiğinde, fasulye açısından böyle bir özellik taşıdığı ortaya çıkmaktadır. İlçe tarımındaki geleneksel yapı, ilçeye yeni çeşitlerin girişine izin vermemiş ve yetiştiriciliğ̈in bölgeye has yerel popülasyonla yapılmasına neden olmuştur. İlçede yetiştiriciliği yapılan beyaz taneli şeker fasulyesi tipindeki popülasyon, lezzet başta olmak üzere, suda fazla şişme, kabuk atmama ve erken pişme gibi özellikleriyle tanınmakta ve piyasada oldukça rağbet görmektedir.

Yurt genelinde tanınan İspir fasulyesi, İspir Esnaf ve Sanatkârlar Odası'nın Türkiye Patent Enstitüsü'ne başvurarak İspir kuru fasulyesinin haklarını almasıyla, artık markalı olarak satılmaya başlanmıştır. Ayrıca, Kuzeydoğu Anadolu Kalkınma Ajansı'nın (KUDAKA) destek verdiği 'Sürdürülebilir Yerel Marka, İspir Kuru Fasulyesi' projesiyle ilçede makineli tarıma geçilmiş ve kuru fasulye için bir de paketleme ünitesi kurulmuştur. İlçede yılda ortalama 400 ton olan üretimin, makineli tarıma geçilmesi le birlikte artarak 600 tona çıkarılması hedeflenmektedir. Bitki ıslahı programlarının en önemli amaçlarından biri yeni çeşitlerin geliştirilmesidir.

Çeşit geliştirmede kullanılan ıslah metotlarının en önemlilerinden biri ise seleksiyondur. Seleksiyon, genotipik varyasyona sahip olan bir popülasyon ya da ekotip içerisinden amaca uygun hattın seçilip ortaya çıkarılması esasına dayanmaktadır (Şehirali ve Özgen, 2006). İspir ilçesinde yerel popülasyonlar ekilmek suretiyle kuru fasulye yetiştiriciliği yapılmakta ancak, yetiştiriciliği yapılan popülasyonun saf olmayışı yetiştiricilik, pazarlama, kullanım ve tüketiminde çeşitli sorunlarla neden olmaktadır. Bu nedenle üretimin standart ve daha verimli hale getirilebilmesi için ilçede yetiştirilen popülasyon içerisinden popülasyonu en iyi şekilde temsil edebilen saf hatların belirlenmesine ihtiyaç duyulmakta ve İspir yerel kuru fasulye popülasyonlarında üstün özelliklere sahip çeşitlerin geliştirilmesine imkan tanıyabilecek geniş bir varyasyon göze çarpmaktadır.

Buradan hareketle, ilçe fasulye tarımında görülen bu problemi gidermeye yönelik olarak yürütülen bu çalışmada; a) bu çeşitliliği bol ve bölgeye has materyalden tek bitki seleksiyonu yöntemiyle saf hatların elde edilmesi ve tanımlamalarının (karakterizasyon) yapılması, b) elde edilen saf hatlar arasından, ileriki çalışmalarda tescil ettirilmek üzere, seleksiyon ıslahı yöntemiyle üstün özellikli olanların belirlenmesi amaçlanmıştır.

\section{Materyal ve Yöntem}

\subsection{Materyal}

\subsubsection{Araştırmada kullanulan İspir fasulye hatlart}

İspir ilçesinde kuru fasulye yetiştiriciliği yapılan köylerdeki tarlalar 2012 yılı hasat döneminde ziyaret edilmiş ve bitki tipi, olgunlaşma ve verim yönünden üstün özelliklere sahip olduğu belirlenen 70 adet tek bitki seçilmiştir. Tek bitkiler (saf hatlar) 2013 yılında ayrı sıralar halinde ekilerek tohum üretimine alınmışlardır. Yeterli miktarda tohum üreten 40 saf hat araştırmamızın materyalini oluşturmuştur (Çizelge 1).

\subsubsection{Araştırma yerinin iklim özellikleri}

Uzun yıllar ortalaması ile kıyaslandığında, araştırmanın yürütüldüğü 2014 yılının daha yağışlı ve sıcak geçtiği, ortalama nispi nemin ise daha düşük olduğu görülmektedir (Çizelge 2). 


\subsubsection{Araştırma yerinin toprak özellikleri}

Deneme arazisi kumlu tınlı yapıda, hafif alkali, tuz içeriği oldukça düşük ve organik madde içeriği azdır. Az kireçli olan deneme arazisi, yeterli seviyede fosfor ve yüksek miktarda potasyum içermektedir (Çizelge 3).

\subsection{Yöntem}

Saf hatlar, bölge için tescil ettirilmiş Elkoca-05 çeşidi ile birlikte 2014 yılında Tesadüf Blokları Deneme Deseninde 3 tekrarlamalı olarak Atatürk Üniversitesi Ziraat Fakültesi’nin Erzurum Merkez'de yer alan istasyonunda morfolojik karakterizasyon, seleksiyon ve verim denemelerine alınmışlardır. Ekim, elle 5-6 cm derinliğe olmak üzere, 13 Mayıs 2014 tarihinde yapılmıştır. Ekim sıklığı, sıra üzeri 6-7 cm ve sıra arası $80 \mathrm{~cm}$ olacak şekilde ayarlanmıştır. Her bir saf hat parselinde $5 \mathrm{~m}$ uzunluğunda bir sıra yer almış ve her sıraya 75 adet tohum ekilmiştir. Deneme alanına ekimle birlikte dekara $4 \mathrm{~kg} \mathrm{~N}$ ve $6 \mathrm{~kg} \mathrm{P}_{2} \mathrm{O}_{5}$ olacak şekilde sirasıyla \% 21 'lik amonyum sülfat ve \% 45'lik triple süperfosfat gübreleri uygulanmıştır (Anonim, 2001). Deneme alanı, ilki çiçeklenme öncesi ve geri kalan üçü bakla bağlama ve tane olum dönemlerinde olmak üzere toplamda dört sefer sulanmıştır. Yabancı otlar gerek duyuldukça çapalanarak kontrol altına alınmıştır. Yolunarak hasat edilen hatlar ayrı ayrı çuvallanarak seraya getirilmiş ve serada 2-3 gün kurutulduktan sonra ayrı ayrı harman edilmişlerdir.

Saf hatların karakterizasyonunda Uluslararası Bitki Gen Kaynakları Araştırma Enstitüsü (IPGRI, Internaional Plant Genetic Resources Institute) ve Avrupa Birliği Bitki Çeşitleri Ofisi (EU-CPVO, European Union Community Plant Variety Office) tarafından geliştirilen çeşit değerlendirme kriterleri esas alınmıştır. Ayrıca, çıkıştan hasada kadarki dönemde Tohumluk Tescil ve Sertifikasyon Merkezi Müdürlüğü’nün Tarımsal Değerleri Ölçme Denemeleri Teknik Talimatında (Anonim, 2001) belirttiği gözlem ve ölçümler yapılmıştır. Bitkisel özelliklere ait değerler her saf hat parselinden tesadüfen seçilen 5 bitki üzerinden hesaplanmıştır.

\subsection{Verilerin değerlendirilmesi}

Elde edilen verilere ait varyans analizleri MSTATC paket programı kullanılarak yapılmıştır. Ortalamalar arasındaki farklar ise Duncan çoklu karşılaştırma testi ile kontrol edilmiştir. Fasulye hatları ayrıca, morfolojik özellikler ile verim ve verim unsurları bakımından Cluster (kümeleme) analizine tabi tutulmuştur. Cluster analizi için SPSS paket programı kullanılmıştır.

Çizelge 1. İspir ilçesinden toplanan saf hatlar, temin edildikleri yer ve lokasyonlar

Table 1. Locations of pure lines collected from Ispir district

\begin{tabular}{lllll}
\hline & & \multicolumn{3}{c}{ Lokasyon } \\
\cline { 2 - 5 } Saf hat no & Temin Edildiği Yer & Enlem & Boylam & Rakım (m) \\
\hline 2, 3, 4, 5, 6, 10, 12, 14, & & & & \\
15, 16, 17, 19, 20, 21 & Öztoprak Köyü & 40.518 & 41.052 & 1431 \\
26 & İspir Merkez Menevşe Mahallesi & 40.485 & 41.002 & 1264 \\
27,28 & İspir Merkez Gaziler Mahallesi & 40.468 & 40.983 & 1168 \\
32, 33, 35 & Yeşilyurt Köyü & 40.518 & 41.069 & 1549 \\
39, 40, 41, 42 & Maden Köyü & 40.435 & 40.851 & 1226 \\
45, 47, 49, 50, 53, 54 & Elmalı Beldesi Ağıldere Köyü & 40.401 & 40.834 & 1470 \\
$57,59,60,61,62,63$ & Ulubel Köyü & 40.418 & 40.868 & 1424 \\
64,65 & Kirazlı Köyü & 40.436 & 40.887 & 1220 \\
67,69 & Maden Köprübaşı Beldesi Akbağ Mahallesi & 40.434 & 40.819 & 1286 \\
\hline
\end{tabular}


Çizelge 2. Erzurum ovasının araştırmanın yürütüldüğü ürün yılı ile uzun yıllar ortalamasına ait bazı iklim verileri Table 2. Some climate data of research year and long-term average in Erzurum plain

\begin{tabular}{|c|c|c|c|c|c|c|c|c|}
\hline \multirow[b]{2}{*}{ İklim Faktörleri } & & \multicolumn{5}{|c|}{ AYLAR } & \multirow[b]{2}{*}{$\begin{array}{l}\text { Gelişme } \\
\text { mevsimi }\end{array}$} & \multirow[b]{2}{*}{ Yillık } \\
\hline & & Mayıs & Haziran & Temmuz & Ağustos & Eylül & & \\
\hline Toplam yağış & 2014 & 115.9 & 24.5 & 44.7 & 4.2 & 47.7 & 237.0 & 408.0 \\
\hline (mm) & UYO & 65.3 & 41.2 & 23.8 & 14.4 & 19.8 & 164.5 & 389.5 \\
\hline Ortalama hava & 2014 & 11.7 & 15.9 & 21.2 & 22.2 & 15.7 & 17.3 & 8.0 \\
\hline S1caklığ $1\left({ }^{\circ} \mathrm{C}\right)$ & UYO & 10.5 & 14.8 & 19.1 & 19.3 & 13.9 & 15.5 & 5.0 \\
\hline Ortalama nispi & 2014 & 65.3 & 50.6 & 43.9 & 37.2 & 48.3 & 49.1 & 61.3 \\
\hline nem (\%) & UYO & 63.9 & 59.1 & 53.6 & 50.2 & 52.5 & 55.8 & 66.4 \\
\hline
\end{tabular}

Çizelge 3. Deneme alanı toprağının bazı fiziksel ve kimyasal özellikleri

Table 3. Some physical and chemical properties of field soil

\begin{tabular}{lll}
\hline Temel özellikler & Analiz sonuçları & Anlamı \\
\hline Tekstür sınıfı & Kumlu tınlı & \\
$\mathrm{pH}$ & 7.7 & Hafif alkali \\
$\mathrm{EC}\left(\mathrm{mmhos} \mathrm{cm}^{-1}\right)$ & 0.12 & Tuzsuz \\
Kireç $(\%)$ & 0.40 & Az kireçli \\
$\mathrm{P}_{2} \mathrm{O}_{5}\left(\mathrm{~kg} \mathrm{da}^{-1}\right)$ & 6.3 & Yeterli \\
$\mathrm{K}_{2} \mathrm{O}\left(\mathrm{kg} \mathrm{da}^{-1}\right)$ & 91.3 & Fazla \\
Organik madde (\%) & 1.47 & Az \\
\hline
\end{tabular}

*Toprak analizleri Atatürk Bahçe Kültürleri Araştırma Enstitüsü analiz laboratuvarında yapılmıştır

\section{Bulgular ve Tartışma}

\subsection{Hatların morfolojik özellikleri}

\subsubsection{Hatların antosiyan varlığı ve büyüme şekilleri}

Yapılan gözlemlerde hatların hiçbirinin antosiyan içermediği ve tamamının yarı sarılıcı karakterde olduğu saptanmıştır.

\subsubsection{Hatlarin yaprak özellikleri}

Hatlardan 22 tanesinin açık yeşil, 17 tanesinin orta yeşil ve yalnızca 1 tanesinin (kayıt no 69) ise koyu yeşil olduğu gözlenmiştir. Yaprak pürüzlülüğü bakımından yapılan gözlemlerde ise denemeye alınan 13 hattın zayıf, 24 hattın orta ve 3 hattın (kayıt no 12, 14 ve 64) ise kuvvetli seviyede pürüzlü olduğu saptanmıştır. Hatlardan 16 tanesinde orta yaprakçı̆̆ın orta, 24 tanesinde ise büyük olduğu tespit edilmiştir. Tüm hatlarda orta yaprakçık şeklinin üçgen olduğu gözlenmiştir. Orta yaprakçık ucunun 28 hatta orta, 12 hatta ise uzun olduğu belirlenmiştir.

\subsubsection{Hatların çiçek özellikleri}

Hatların tamamında braktenin mızrak biçiminde; boyutunun 5 hatta küçük (kayıt no 19, 40, 49, 57 ve 69), diğer 35 hatta büyük; renginin ise 2 hatta (kayıt no 49 ve 69) açık viole, 38 genotipte ise yeşil olduğu belirlenmiştir. Hatlar arasında bayrak yaprak rengi bakımından varyasyon bulunduğu ve bayrak yaprağın 7 hatta menekşe (kayıt no 4, 17, $19,20,28,32$ ve 59), 1 hatta beyaz (kayıt no 40) ve diğer 32 hatta ise pembe renkli olduğu belirlenmiştir. Kanatçık rengi bakımından hatlar değerlendirildiğinde ise 40 nolu hat hariç, diğer hatların pembe renkli kanatçığa sahip olduğu tespit edilmiştir. Kanatçıkların açılım durumu bakımından yapılan gözlemlerde tüm hatlarda kanatçıkların birbirinden iyice ayrık olduğu gözlenmiştir. Her saf hat parselinden rastgele alınan 10 çiçeğin ve sapının uzunluğu ölçülmüş ve hatların çiçek uzunluğunun $9.8 \mathrm{~mm}$ (kayıt no 63 ve 65) ile $18.8 \mathrm{~mm}$ (kayıt no 57) arasında değiştiği saptanmıştır (Çizelge 4). Çiçek sap uzunluğu bakımından da hatlar arasında varyasyon bulunduğu belirlenmiş ve 
hatların çiçek sap uzunlukları $7.8 \mathrm{~mm}$ (kayıt no 15) ile $23.8 \mathrm{~mm}$ (kayıt no 64) arasında olmak üzere geniş bir aralıkta değişim göstermiştir. (Çizelge 4).

\subsubsection{Hatların bakla özellikleri}

Tüm hatlarda bakla zemin renginin yeşil; koyuluğunun ise 4 hatta hafif (kayıt no 32, 40, 62 ve 69), geri kalan 36 hatta ise orta olduğu tespit edilmiştir. Diğer taraftan, olgunluk dönemi ilerledikçe bütün hatların baklalarında viole olmak üzere ikinci renk oluşumu gözlenmiştir. Bu ikinci rengin yoğunluğu bakımından yapılan gözlemlerde ise ikinci renk yoğunluğunun bütün hatlarda orta seviyede olduğu belirlenmiştir. Tüm hatlarda baklanın kılçıklı, kesit şeklinin eliptik, genişliğinin orta, gaga kıvrılmasının çok güçsüz, gaganın oluşum şeklinin orta, gaganın uzun, baklanın kıvrım şeklinin orta ve bakla kıvrımının iç bükey olduğu belirlenmiştir.

\subsubsection{Hatların tohum özellikleri}

Hatlardan sekiz tanesinde (kayıt no 3, 5, 12, 20, 39, 40, 41 ve 64) tohum şeklinin dairesel-eliptik, geri kalanında ise dairesel olduğu belirlenmiştir. Hatların tamamında tohumların tek renkli ve beyaz olduğu ayrıca, hilum halkasının da tohum rengi ile aynı olduğu gözlenmiştir.

\subsection{Hatların fenolojik ve tarımsal özellikleri}

\subsection{1 Çıkış süresi}

İlkbahardaki düşük toprak sıcaklıkları fasulyede çimlenme hızını yavaşlatarak çıkışı geciktirmektedir (Mohammed et al., 1988). Ancak, çimlenme için toplam sıcaklık isteği yönünden fasulye genotipleri arasında önemli farklılıklar görülebilmekte ve düşük toplam sıcaklık isteğine sahip olanlar toprak sıcaklığının minimum çimlenme sıcaklık isteğinin üzerinde olduğu durumlarda hızlı bir şekilde çimlenip kısa sürede çıkış yapabilmektedirler (Wagenvoort and Bierhuizen, 1977; Kantar ve Elkoca, 2001). Araştırmamızda da çıkış süresinin genotipik etkiye bağlı olarak çok önemli $(\mathrm{p}<0.01)$ değişim gösterdiği belirlenmiştir (Çizelge 5). Hatların çıkış süresi 15.0 ile 17.7 gün arasında yer almış ve 2.7 günlük bir varyasyon meydana gelmiştir (Çizelge 5). Hatlardan 37 tanesi kontrol çeşidinden (17.0 gün) iki gün daha erken $(15.0$ gün $)$ çııış yapmış ve bu fark istatistiki olarak çok önemli bulunmuştur. Hatlardan üç tanesi ise (kayıt no 40, 59 ve 63) kontrol çeşidi ile beraber en geç çıkış yapan grup içerisinde yer almıştır.

Çizelge 4. İspir fasulye hatlarının çiçek ve çiçek sap uzunlukları

Table 4. Lengths of flower and flower stem of İspir bean lines

\begin{tabular}{llllll}
\hline Hat no & $\begin{array}{l}\text { Çiçek uzunluğu } \\
(\mathrm{mm})\end{array}$ & $\begin{array}{l}\text { Çiçek sap } \\
\text { uzunluğu }(\mathrm{mm})\end{array}$ & Hat no & $\begin{array}{l}\text { Çiçek uzunluğu } \\
(\mathrm{mm})\end{array}$ & $\begin{array}{l}\text { Çiçek sap } \\
\text { uzunluğu }(\mathrm{mm})\end{array}$ \\
\hline 2 & 13.0 & 10.0 & 39 & 16.3 & 9.5 \\
3 & 17.0 & 12.0 & 40 & 10.3 & 14.8 \\
4 & 15.0 & 9.5 & 41 & 11.3 & 9.5 \\
5 & 15.3 & 12.3 & 42 & 12.0 & 13.0 \\
6 & 10.3 & 10.5 & 45 & 11.5 & 10.3 \\
10 & 10.8 & 9.5 & 47 & 14.0 & 14.0 \\
12 & 13.3 & 10.3 & 49 & 17.5 & 20.0 \\
14 & 13.5 & 13.3 & 50 & 15.0 & 16.3 \\
15 & 10.0 & 7.8 & 53 & 13.5 & 14.0 \\
16 & 10.8 & 18.0 & 54 & 13.3 & 12.3 \\
17 & 14.0 & 9.3 & 57 & 18.8 & 11.3 \\
19 & 11.0 & 8.5 & 59 & 11.5 & 12.5 \\
20 & 13.3 & 9.5 & 60 & 14.3 & 13.0 \\
21 & 12.3 & 9.5 & 61 & 16.0 & 8.8 \\
26 & 12.0 & 12.5 & 62 & 16.5 & 13.3 \\
27 & 13.0 & 12.0 & 63 & 9.8 & 12.3 \\
28 & 14.3 & 11.5 & 64 & 12.3 & 23.8 \\
32 & 11.0 & 18.5 & 65 & 9.8 & 9.8 \\
33 & 14.8 & 16.5 & 67 & 14.3 & 8.8 \\
35 & 14.8 & 8.8 & 69 & 13.5 & 8.5 \\
\hline
\end{tabular}




\subsection{2 Çiçeklenme süresi}

Hatların çiçeklenme süresi 61.3 gün (kayıt no 15) ile 68.3 gün (kayıt no 12 ve 65) arasında değişmiş ancak, çiçeklenme süresi bakımından hatlar arasında istatistiksel olarak önemli bir farklılığın olmadığı belirlenmiştir (Çizelge 5). Standart çeşitte çiçeklenme ekimden 65.7 gün sonra gerçekleşirken, istatistiki olarak önemsiz olmakla birlikte, 22 hat standart çeşitten yaklaşık 1 ile 5 gün daha önce, 9 hat ise 1 ile 3 gün daha geç çiçeklenmiştir (Çizelge 5).

\subsubsection{Fizyolojik olum süresi}

Erzurum ve benzer ekolojilerde fasulyenin soğuk ve don zararına uğramadan gelişebileceği dönem oldukça kısadır. Bu nedenle kısa sürede gelişerek, sonbahar ilk donlarından önce olgunlaşan çeşitlerin yetiştirilmesi, bu tip bölgelerde fasulye tarımında ortaya çıkabilecek risklerin giderilmesi yönünden büyük önem taşımaktadır (Elkoca ve Kantar, 2004). Çiçeklenme ve olgunlaşma için ihtiyaç duyulan toplam sıcaklık isteği yönünden genotipler arasında önemli farklar bulunabilmektedir. Toplam sıcaklık isteği düşük olan genotipler daha erken çiçeklenip olgunlaşırken, toplam sıcaklık isteği yüksek olanlarda çiçeklenme ve olgunlaşma gecikmektedir (Ustaoğlu, 2008). Bu araştırmaya ait varyans analizi sonuçları da genotipik etkinin olgunlaşma süresi üzerinde önemli olduğunu göstermiştir (Çizelge 5). Erkenciliği ile tescil ettirilen Elkoca-05 en kısa sürede olgunlaşırken (125.3 gün), İspir fasulye hatlarında olgunlaşma süresi 129.7 ile 140.0 gün arasında değişim göstermiştir. Hatlardan 10 tanesinde (kayıt no 10, 16, 17, 19, 21, 40, 49, 54, 60 ve 69) olgunlaşma süresi 129.7 ile 132.0 gün arasında değişim göstermiş ve bu hatlar standart çeşitle aynı grup içerisinde yer alarak dikkat çekici bulunmuşlardır. Diğer hatlar ise standart çeşitten önemli seviyede daha geç oluma ulaşmışlardır (Çizelge 5).

\subsubsection{Bitki boyu}

İspir fasulye hatlarının test edildiği bu çalışmada, bitki boyu bakımından genotipik etkinin önemli olduğu belirlenmiştir (Çizelge 5). Standart çeşitte $89.6 \mathrm{~cm}$ ölçülen bitki boyu, İspir hatlarında $85.1 \mathrm{~cm}$ ile $112.3 \mathrm{~cm}$ arasında önemli bir varysayon göstermiştir. En kısa bitki boyu $16(85.1 \mathrm{~cm}), 5(87.7 \mathrm{~cm})$ ve 4 nolu hatlarda $(89.3 \mathrm{~cm})$ ölçülürken, dokuz hat (kayıt no 6, 17, 33, 59, 65, 32, 63, 42 ve 40) bir metreden daha uzun (101.1-112.3 cm) bitki boyuna sahip olmuştur (Çizelge 5). Fasulyede bitki boyu yüksek bir kalıtım derecesine (\% 84.6-90.0) sahiptir (Çiftçi ve Şehirali, 1984). Bu nedenle diğer pek çok çalışmada da genetik yapıdaki farklılıkların bir sonucu olarak, fasulye çeşit ve genotipleri arasında bitki boyu bakımından önemli varyasyonların bulunduğu rapor edilmiştir (Akçin, 1974; Kantar ve ark., 2010; Bozoğlu ve Sözen, 2007; Ceyhan ve ark., 2009).

Çizelge 5. İspir fasulye hatlarının bazı fenolojik ve tarımsal özellikleri Table 5. Some phenological and agronomical properties of İspir bean lines

\begin{tabular}{lllllll}
\hline Hat no & $\begin{array}{l}\text { Ç1k1ş } \\
\text { süresi } \\
\text { (gün) }\end{array}$ & $\begin{array}{l}\text { Çiçeklenme } \\
\text { süresi (gün) }\end{array}$ & $\begin{array}{l}\text { Fizyolojik } \\
\text { olum süresi } \\
\text { (gün) }\end{array}$ & $\begin{array}{l}\text { Bitki boyu } \\
\text { (cm) }\end{array}$ & $\begin{array}{l}\text { İlk bakla } \\
\text { yüksekliği } \\
\text { (cm) }\end{array}$ & $\begin{array}{l}\text { Dal sayıs1 } \\
\text { (adet bitki }{ }^{-1} \text { ) }\end{array}$ \\
\hline 2 & $15 \mathrm{c}$ & 64.3 & $132.3 \mathrm{~b}-\mathrm{e}$ & $95.4 \mathrm{~b}-\mathrm{g}$ & $13.7 \mathrm{cde}$ & $3.53 \mathrm{~d}$ \\
3 & $15 \mathrm{c}$ & 66.0 & $134.0 \mathrm{a}-\mathrm{e}$ & $91.3 \mathrm{efg}$ & $13.3 \mathrm{cde}$ & $3.73 \mathrm{~cd}$ \\
4 & $15 \mathrm{c}$ & 63.0 & $132.3 \mathrm{~b}-\mathrm{e}$ & $89.3 \mathrm{fg}$ & $12.5 \mathrm{cde}$ & $3.73 \mathrm{~cd}$ \\
5 & $16.3 \mathrm{abc}$ & 65.7 & $137.0 \mathrm{a}-\mathrm{d}$ & $87.7 \mathrm{fg}$ & $13.1 \mathrm{cde}$ & $3.80 \mathrm{~cd}$ \\
6 & $15 \mathrm{c}$ & 67.0 & $137.7 \mathrm{abc}$ & $101.1 \mathrm{a}-\mathrm{g}$ & $14.5 \mathrm{cde}$ & $4.80 \mathrm{ab}$ \\
10 & $15 \mathrm{c}$ & 63.3 & $129.7 \mathrm{ef}$ & $94.4 \mathrm{~b}-\mathrm{g}$ & $14.1 \mathrm{cde}$ & $3.80 \mathrm{~cd}$ \\
12 & $15 \mathrm{c}$ & 68.3 & $140.0 \mathrm{a}$ & $95.2 \mathrm{~b}-\mathrm{g}$ & $14.9 \mathrm{~b}-\mathrm{e}$ & $3.67 \mathrm{~cd}$ \\
14 & $15.7 \mathrm{bc}$ & 62.7 & $137.7 \mathrm{abc}$ & $93.7 \mathrm{c}-\mathrm{g}$ & $13.9 \mathrm{cde}$ & $3.73 \mathrm{~cd}$ \\
15 & $16.3 \mathrm{abc}$ & 61.3 & $134.0 \mathrm{a}-\mathrm{e}$ & $92.7 \mathrm{c}-\mathrm{g}$ & $12.4 \mathrm{cde}$ & $3.93 \mathrm{~cd}$ \\
16 & $15 \mathrm{c}$ & 63.3 & $132.0 \mathrm{~b}-\mathrm{f}$ & $85.1 \mathrm{~g}$ & $12.2 \mathrm{cde}$ & $3.53 \mathrm{~d}$ \\
17 & $15 \mathrm{c}$ & 63.0 & $131.7 \mathrm{~b}-\mathrm{f}$ & $102.4 \mathrm{a}-\mathrm{f}$ & $14.5 \mathrm{cde}$ & $3.93 \mathrm{~cd}$ \\
19 & $15 \mathrm{c}$ & 63.7 & $129.7 \mathrm{ef}$ & $93.7 \mathrm{c}-\mathrm{g}$ & $12.7 \mathrm{cde}$ & $4.07 \mathrm{bcd}$ \\
20 & $15 \mathrm{c}$ & 61.7 & $137.0 \mathrm{a}-\mathrm{d}$ & $95.1 \mathrm{~b}-\mathrm{g}$ & $12.8 \mathrm{cde}$ & $3.93 \mathrm{~cd}$ \\
21 & $15 \mathrm{c}$ & 62.3 & $130.3 \mathrm{def}$ & $90.7 \mathrm{efg}$ & $12.1 \mathrm{de}$ & $3.60 \mathrm{~cd}$ \\
26 & $15 \mathrm{c}$ & 67.3 & $137.7 \mathrm{abc}$ & $97.3 \mathrm{a}-\mathrm{g}$ & $12.0 \mathrm{de}$ & $3.67 \mathrm{~cd}$ \\
27 & $15 \mathrm{c}$ & 63.7 & $134.7 \mathrm{a}-\mathrm{e}$ & $93.7 \mathrm{c}-\mathrm{g}$ & $12.8 \mathrm{cde}$ & $3.93 \mathrm{~cd}$
\end{tabular}




\begin{tabular}{|c|c|c|c|c|c|c|}
\hline 28 & $15 \mathrm{c}$ & 66.7 & 132.7 b-e & 99.5 a-g & 14.1 cde & $3.73 \mathrm{~cd}$ \\
\hline 32 & $15 \mathrm{c}$ & 67.7 & $138.3 \mathrm{ab}$ & $107.7 \mathrm{a}-\mathrm{d}$ & $19.2 \mathrm{a}$ & $4.27 \mathrm{bcd}$ \\
\hline 33 & $15 \mathrm{c}$ & 65.7 & $140.0 \mathrm{a}$ & 102.9 a-f & $15.1 \mathrm{~b}-\mathrm{e}$ & $4.13 \mathrm{bcd}$ \\
\hline 35 & $15 \mathrm{c}$ & 63.3 & 132.3 b-e & $97.9 \mathrm{a}-\mathrm{g}$ & 13.3 cde & 3.87 cd \\
\hline 39 & 15 c & 63.3 & 133.0 b-e & 90.7 efg & 12.2 cde & $3.53 \mathrm{~d}$ \\
\hline 40 & $17 \mathrm{ab}$ & 68.0 & $131.0 \mathrm{c}-\mathrm{f}$ & $112.3 \mathrm{a}$ & $17.9 \mathrm{ab}$ & $4.27 \mathrm{bcd}$ \\
\hline 41 & 15 c & 63.7 & 135.7 a-e & $99.4 \mathrm{a}-\mathrm{g}$ & 13.9 cde & $4.00 \mathrm{bcd}$ \\
\hline 42 & $15 \mathrm{c}$ & 67.3 & $140.0 \mathrm{a}$ & $109.9 \mathrm{ab}$ & 15.8 bc & $4.47 \mathrm{abc}$ \\
\hline 45 & $15 \mathrm{c}$ & 64.5 & $140.0 \mathrm{a}$ & 94.3 b-g & 12.2 cde & $4.27 \mathrm{bcd}$ \\
\hline 47 & $15 \mathrm{c}$ & 64.0 & 132.3 b-e & $92.5 \mathrm{~d}-\mathrm{g}$ & $11.6 \mathrm{e}$ & $4.00 \mathrm{bcd}$ \\
\hline 49 & $15 \mathrm{c}$ & 63.3 & $131.0 \mathrm{c}-\mathrm{f}$ & $92.1 \mathrm{~d}-\mathrm{g}$ & 12.0 de & $3.60 \mathrm{~cd}$ \\
\hline 50 & $15 \mathrm{c}$ & 66.0 & 135.3 a-e & 99.9 a-g & 12.3 cde & $4.13 \mathrm{bcd}$ \\
\hline 53 & $15 \mathrm{c}$ & 66.0 & 134.0 a-e & 93.7 c-g & 12.5 cde & $3.93 \mathrm{~cd}$ \\
\hline 54 & $16.3 \mathrm{abc}$ & 65.7 & 131.7 b-f & 94.4 b-g & 13.1 cde & $4.20 \mathrm{bcd}$ \\
\hline 57 & $15 \mathrm{c}$ & 65.0 & 134.0 a-e & 94.4 b-g & $11.8 \mathrm{de}$ & $3.80 \mathrm{~cd}$ \\
\hline 59 & $17.7 \mathrm{a}$ & 65.3 & 135.3 a-e & $103.7 \mathrm{a}-\mathrm{f}$ & $11.8 \mathrm{de}$ & $4.27 \mathrm{bcd}$ \\
\hline 60 & 15 c & 64.3 & $132.0 \mathrm{~b}-\mathrm{f}$ & 94.3 b-g & 12.5 cde & $4.33 \mathrm{a}-\mathrm{d}$ \\
\hline 61 & $15 \mathrm{c}$ & 65.3 & 135.3 a-e & 96.4 b-g & 13.5 cde & $3.80 \mathrm{~cd}$ \\
\hline 62 & $15 \mathrm{c}$ & 64.0 & 134.7 a-e & 90.9 efg & 13.8 cde & $3.67 \mathrm{~cd}$ \\
\hline 63 & $17 \mathrm{ab}$ & 63.0 & $137.0 \mathrm{a}-\mathrm{d}$ & $108.7 \mathrm{a}-\mathrm{d}$ & 12.7 cde & $3.80 \mathrm{~cd}$ \\
\hline 64 & $15 \mathrm{c}$ & 65.3 & 134.0 a-e & $97.7 \mathrm{a}-\mathrm{g}$ & 14.3 cde & $3.93 \mathrm{~cd}$ \\
\hline 65 & $15 \mathrm{c}$ & 68.3 & $137.0 \mathrm{a}-\mathrm{d}$ & 106.0 a-e & 14.5 cde & $4.07 \mathrm{bcd}$ \\
\hline 67 & $15 \mathrm{c}$ & 62.0 & $137.7 \mathrm{abc}$ & $92.3 \mathrm{~d}-\mathrm{g}$ & 12.5 cde & $3.60 \mathrm{~cd}$ \\
\hline 69 & $15 \mathrm{c}$ & 66.7 & $131.0 \mathrm{c}-\mathrm{f}$ & $98.7 \mathrm{a}-\mathrm{g}$ & 14.0 cde & $4.47 \mathrm{abc}$ \\
\hline Elkoca-05 & $17 \mathrm{ab}$ & 65.7 & $125.3 \mathrm{f}$ & $89.6 \mathrm{fg}$ & $15.3 \mathrm{bcd}$ & $5.07 \mathrm{a}$ \\
\hline$V K(\%)$ & 5.6 & 4.5 & 3.1 & 8.2 & 13.1 & 10.7 \\
\hline \multicolumn{7}{|c|}{ F Değerleri } \\
\hline \multirow[t]{2}{*}{ Genotip } & 2.08 & 1.27 & 1.87 & 1.85 & 2.39 & 1.92 \\
\hline & $\mathrm{P}<0.01$ & Önemsiz & $\mathrm{P}<0.01$ & $\mathrm{P}<0.05$ & $\mathrm{P}<0.01$ & $\mathrm{P}<0.01$ \\
\hline
\end{tabular}

\subsubsection{Ilk bakla yükseklĭgi}

İlk bakla yüksekliği makineli hasada uygunluk bakımından önemli bir parametre olup, dik gelişen, uzun boylu ve baklaları yüksekte teşekkül eden çeşitler mekanik olarak hasat edilebilmektedirler. Varyans analizi sonuçları ilk bakla yüksekliği bakımından genotipler arasındaki farkların çok önemli olduğunu göstermiştir (Çizelge 5). Standart çeşitte $15.3 \mathrm{~cm}$ olan ilk bakla yüksekliği, İspir fasulye hatlarında $11.6 \mathrm{~cm}$ ile 19.2 arasında değişim göstermiştir. Üç hat (kayıt no 47, 57 ve 59) en kısa $(11.6-11.8 \mathrm{~cm})$ ilk bakla yüksekliğine sahip olurken, özellikle 40 ve 32 nolu hatlar uzun ilk bakla yüksekliği değeri ile (sırasıyla 17.9 ve $19.2 \mathrm{~cm}$ ) oldukça dikkat çekici bulunmuşladır (Çizelge 5). Farklı ekolojik koşullarda yürütülen diğer araştırmalarda da ilk bakla yüksekliğinin çeşit ve genotiplere bağlı olarak $9.9 \mathrm{~cm}$ ile $29.3 \mathrm{~cm}$ arasında olmak üzere önemli varyasyon gösterdiği rapor edilmiştir (Bozoğlu, 1995; Anlarsal ve ark., 2000; Düzdemir ve Akdağ, 2001).

\subsubsection{Bitkide dal saylsl}

Bitkide dal sayısı genotiplere göre değişmiş ve genotipler arasındaki farklılık çok önemli $(\mathrm{p}<0.01)$ olmuştur (Çizelge 5). En yüksek dal sayısı (5.07 adet) denemede kontrol olarak kullanılan Elkoca-05 çeşidinde belirlenmiş ve bitki başına dal sayısı 4.33-4.80 adet arasında değişen 6, 42, 69 ve 60 nolu hatlar standart çeşitle istatistiki olarak aynı grup içerisinde yer almıştır. En düşük dal sayısı 3.53 adet ile 16, 2 ve 39 nolu hatlarda belirlenmiştir (Çizelge 5). Fasulyede bitki başına dal sayısının Karaman ekolojik koşullarında 4.11-4.66 adet (Önder ve Şentürk, 1996), Samsun ekolojik koşullarında 1.27-1.92 adet (Pekşen ve Gülümser, 2005), Erzurum ekolojik koşullarında 2.2-3.7 adet (Dumlu, 2009) ve Yozgat ekolojik koşullarında ise 1.44-4.89 adet olmak üzere (Varankaya, 2011) diğer çalışmalarda da genotipler arasında önemli değişim gösterdiği saptanmıştır. 


\subsubsection{Bitkide bakla sayısı}

Varyans analizi sonuçları bitkide bakla sayısı bakımından genotipler arasında çok önemli $(\mathrm{p}<0.01)$ farkların bulunduğunu göstermiştir (Çizelge 6). Standart çeşitte bitki başına 21.2 adet bakla teşekkül ederken, İspir fasulye hatlarında bitki başına bakla sayısı 15.8 adet (kayıt no 14) ile 23.5 adet (kayıt no 19) arasında çok önemli bir değişim göstermiştir. 14 nolu hat hariç, hatların tamamı bakla sayısı bakımından standart çeşitle aynı grup içerisinde yer almıştır. Yapılan diğer çalışmalarda da bitki başına bakla sayısının Çukurova koşullarında 11.4-18.0 adet (Anlarsal ve ark., 2000), Erzurum ekolojik koşullarında 11.3-17.3 adet (Elkoca ve Kantar, 2004) Samsun ekolojik koşullarında 7.2-13.5 (Pekşen ve Gülümser, 2005) ve Yozgat ekolojik koşullarında ise 7.5-18.3 adet (Varankaya, 2011) olmak üzere çeşit ve genotipler arasında önemli varyasyon gösterdiği saptanmıştır.

\subsubsection{Baklada tane saylst}

Standart çeşitte 4.27 adet olan bakladaki tane sayısı, İspir fasulye hatlarında 3.37 adet ile 5.93 adet arasında önemli değişim göstermiştir. 40 nolu hattın bakladaki tane sayısı (5.93 adet) diğer hatların tamamından ve standart çeşitten önemli seviyede yüksek olmuş ve bu özelliği ile oldukça dikkat çekici bulunmuştur. Bakladaki tane sayısı 3.53 ile 4.80 adet arasında değişen 27 adet hat ise standart çeşitle aynı istatistiki grup içerisinde yer almıştır (Çizelge 6). Farklı fasulye genotipleri kullanılarak yürütülen diğer çalışmalarda, baklada tane sayısının Erzurum ekolojik koşullarında 3.5-4.2 adet (Elkoca ve Kantar, 2004), Samsun ekolojik koşullarında 3.24-6.06 adet (Pekşen ve Gülümser, 2005), Konya ekolojik koşullarında 3.53-4.89 adet (Ülker ve Ceyhan, 2008) ve Yozgat ekolojik koşullarında ise 2.35-3.68 adet arasında değişim gösterdiği rapor edilmiştir (Varankaya, 2011).

\subsubsection{Yüz tane ă̆ırlı̆̆l}

Genotiplerin yüz tane ağırlığı 49.63 ile 63.46 g arasında değişmiş ve varyans analizi sonuçları genotipler arasındaki farklılıkların çok önemli olduğunu göstermiştir (Çizelge 6). Kontrol olarak kullanılan Elkoca-05, İspir fasulye hatlarının tamamından önemli seviyede düşük yüz tane ağırlığına (49.63 g) sahip olmuştur. İspir fasulye hatlarının yüz tane ağırlıkları ise $54.11 \mathrm{~g}$ ile $63.46 \mathrm{~g}$ arasında çok önemli bir değişim göstermiştir. En yüksek yüz tane ağırlığı $(60.15-63.46$ g) 4, 16, 17, 19, 21, 26 ve 54 nolu hatlarda belirlemiştir. En düşük yüz tane ağırlığı ise (54.11-54.81 g) 39, 40, 57 ve 65 nolu hatlarda tespit edilmiştir (Çizelge 6). Farklı fasulye genotipleri ile çalışan diğer araştırıcılar da yüz tane ağırlığının Van ekolojik koşullarında 16.8-44.0 g (Çiftçi ve Yılmaz 1992), Tokat ekolojik koşullarında 23.4-62.8 g (Akdağ ve Şahin 1994), Karaman ekolojik koşullarında 17.3-46.3 g (Önder ve Şentürk, 1996) ve Yozgat ekolojik koşullarında ise 25.9-46.9 g (Varankaya, 2011) arasında olmak üzere, genotiplere göre önemli değişim gösterdiğini saptamışlardır.

\subsubsection{Biyolojik verim}

Varyans analizi sonucuna göre, biyolojik verim üzerine genotip etkisi çok önemli $(\mathrm{p}<0.01)$ olmuştur (Çizelge 6). Genotiplerin biyolojik verimi $379.2 \mathrm{~g} \mathrm{~m}^{-2}$ ile $719.2 \mathrm{~g} \mathrm{~m}^{-2}$ arasında olmak üzere oldukça önemli bir varyasyon göstermiş ve ortalama biyolojik verim $479.2 \mathrm{~g} \mathrm{~m}^{-2}$ olarak gerçekleşmiştir. En yüksek biyolojik verim 6 (719.2 $\mathrm{g} \mathrm{m}^{-}$

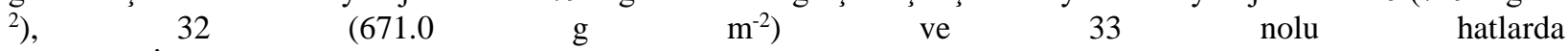

Çizelge 6. İspir fasulye hatlarında tane verimi ve bazı verim unsurları

Table 6. Seed yield and some yield components of İspir bean lines

\begin{tabular}{lllllll}
\hline Hat no & $\begin{array}{l}\text { Bakla sayıs1 } \\
\left(\text { adet bitki }^{-1}\right)\end{array}$ & $\begin{array}{l}\text { Baklada } \\
\text { tane sayısı } \\
\text { (adet) }\end{array}$ & $\begin{array}{l}\text { Yüz tane } \\
\text { ağırlığ }(\mathrm{g})\end{array}$ & $\begin{array}{l}\text { Biyolojik } \\
\text { verim }\left(\mathrm{g} \mathrm{m}^{-2}\right)\end{array}$ & $\begin{array}{l}\text { Tane verimi } \\
\left(\mathrm{g} \mathrm{m}^{-2}\right)\end{array}$ & $\begin{array}{l}\text { Hasat } \\
\text { indeksi } \\
(\%)\end{array}$ \\
\hline 2 & $16.9 \mathrm{~d}-\mathrm{g}$ & $3.53 \mathrm{e}-\mathrm{h}$ & $57.30 \mathrm{c}-\mathrm{h}$ & $422.1 \mathrm{c}-\mathrm{f}$ & $151.5 \mathrm{f}-\mathrm{m}$ & $35.6 \mathrm{~b}-\mathrm{j}$ \\
3 & $19.5 \mathrm{a}-\mathrm{g}$ & $3.60 \mathrm{e}-\mathrm{h}$ & $57.35 \mathrm{c}-\mathrm{h}$ & $525.7 \mathrm{bcd}$ & $189.2 \mathrm{~b}-\mathrm{i}$ & $36.1 \mathrm{a}-\mathrm{j}$ \\
4 & $18.7 \mathrm{a}-\mathrm{g}$ & $3.5 \mathrm{fgh}$ & $63.31 \mathrm{ab}$ & $484.8 \mathrm{~b}-\mathrm{f}$ & $199.1 \mathrm{a}-\mathrm{g}$ & $41.0 \mathrm{a}-\mathrm{f}$ \\
5 & $16.3 \mathrm{fg}$ & $3.67 \mathrm{~d}-\mathrm{h}$ & $59.99 \mathrm{a}-\mathrm{f}$ & $379.2 \mathrm{f}$ & $121.9 \mathrm{~m}$ & $33.0 \mathrm{e}-\mathrm{k}$ \\
6 & $20.7 \mathrm{a}-\mathrm{g}$ & $4.57 \mathrm{~b}$ & $57.24 \mathrm{c}-\mathrm{h}$ & $719.2 \mathrm{a}$ & $243.2 \mathrm{a}$ & $34.2 \mathrm{~d}-\mathrm{k}$ \\
10 & $19.7 \mathrm{a}-\mathrm{g}$ & $3.60 \mathrm{e}-\mathrm{h}$ & $58.21 \mathrm{~b}-\mathrm{h}$ & $473.3 \mathrm{~b}-\mathrm{f}$ & $187.2 \mathrm{~b}-\mathrm{i}$ & $39.7 \mathrm{a}-\mathrm{h}$ \\
12 & $16.3 \mathrm{efg}$ & $3.43 \mathrm{fgh}$ & $55.08 \mathrm{e}-\mathrm{h}$ & $447.5 \mathrm{~b}-\mathrm{f}$ & $125.6 \mathrm{~lm}$ & $28.0 \mathrm{jk}$ \\
14 & $15.8 \mathrm{~g}$ & $3.53 \mathrm{e}-\mathrm{h}$ & $59.09 \mathrm{a}-\mathrm{h}$ & $474.4 \mathrm{~b}-\mathrm{f}$ & $151.2 \mathrm{f}-\mathrm{m}$ & $31.9 \mathrm{~g}-\mathrm{k}$ \\
15 & $17.9 \mathrm{c}-\mathrm{g}$ & $3.50 \mathrm{fgh}$ & $58.25 \mathrm{~b}-\mathrm{h}$ & $417.0 \mathrm{def}$ & $148.9 \mathrm{~g}-\mathrm{m}$ & $35.3 \mathrm{~b}-\mathrm{j}$
\end{tabular}




\begin{tabular}{|c|c|c|c|c|c|c|}
\hline 16 & $17.1 \mathrm{c}-\mathrm{g}$ & 3.60 e-h & $62.01 \mathrm{abc}$ & $426.1 \mathrm{c}-\mathrm{f}$ & 182.9 b-k & $43.0 \mathrm{ab}$ \\
\hline 17 & 21.3 a-e & $3.50 \mathrm{fgh}$ & 63.46 a & $536.8 \mathrm{bcd}$ & 207.2 a-e & $38.5 \mathrm{a}-\mathrm{i}$ \\
\hline 19 & $23.5 \mathrm{a}$ & 3.60 e-h & $62.11 \mathrm{abc}$ & 519.6 b-e & $217.5 \mathrm{abc}$ & $41.8 \mathrm{a}-\mathrm{d}$ \\
\hline 20 & $19.5 \mathrm{a}-\mathrm{g}$ & 3.60 e-h & 58.96 a-h & 489.3 b-f & 165.4 c-m & $34.0 \mathrm{~d}-\mathrm{k}$ \\
\hline 21 & $17.1 \mathrm{c}-\mathrm{g}$ & $3.43 \mathrm{fgh}$ & 61.95 abc & 395.4 ef & $132.1 \mathrm{j}-\mathrm{m}$ & $33.5 \mathrm{~d}-\mathrm{k}$ \\
\hline 26 & 18.2 b-g & $3.43 \mathrm{fgh}$ & 60.15 a-e & 491.7 b-f & 168.3 c-m & $34.1 \mathrm{~d}-\mathrm{k}$ \\
\hline 27 & $21.3 \mathrm{a}-\mathrm{f}$ & $3.37 \mathrm{~h}$ & $56.24 \mathrm{~d}-\mathrm{h}$ & 505.5 b-e & $170.0 \mathrm{c}-\mathrm{m}$ & 33.9 d-k \\
\hline 28 & $20.3 \mathrm{a}-\mathrm{g}$ & $3.70 \mathrm{c}-\mathrm{h}$ & $59.80 \mathrm{a}-\mathrm{f}$ & 444.8 b-f & 169.5 c-m & 38.7 a-i \\
\hline 32 & $19.5 \mathrm{a}-\mathrm{g}$ & $4.13 \mathrm{~b}-\mathrm{g}$ & $57.02 \mathrm{c}-\mathrm{h}$ & $671.0 \mathrm{a}$ & $211.4 \mathrm{a}-\mathrm{d}$ & 31.4 h-k \\
\hline 33 & $19.7 \mathrm{a}-\mathrm{g}$ & 4.40 bc & $57.72 \mathrm{c}-\mathrm{h}$ & $661.8 \mathrm{a}$ & $241.9 \mathrm{a}$ & 36.6 a-i \\
\hline 35 & $17.1 \mathrm{c}-\mathrm{g}$ & $3.43 \mathrm{fgh}$ & $58.06 \mathrm{c}-\mathrm{h}$ & 518.0 b-e & $193.5 \mathrm{a}-\mathrm{h}$ & $37.2 \mathrm{a}-\mathrm{i}$ \\
\hline 39 & $17.1 \mathrm{c}-\mathrm{g}$ & 3.57 e-h & $54.51 \mathrm{gh}$ & 457.5 b-f & 184.4 b-j & $40.2 \mathrm{a}-\mathrm{g}$ \\
\hline 40 & 17.5 c-g & 5.93 a & $54.11 \mathrm{~h}$ & 545.6 bc & $234.0 \mathrm{ab}$ & $42.7 \mathrm{abc}$ \\
\hline 41 & 17.9 c-g & 3.87 c-h & 55.91 e-h & 478.3 b-f & 157.3 e-m & $32.8 \mathrm{f}-\mathrm{k}$ \\
\hline 42 & $22.1 \mathrm{abc}$ & $4.37 \mathrm{bcd}$ & $56.55 \mathrm{~d}-\mathrm{h}$ & 506.3 b-e & $135.5 \mathrm{i}-\mathrm{m}$ & $26.9 \mathrm{k}$ \\
\hline 45 & $21.1 \mathrm{a}-\mathrm{f}$ & $3.80 \mathrm{c}-\mathrm{h}$ & $59.23 \mathrm{a}-\mathrm{h}$ & 475.9 b-f & $161.9 \mathrm{~d}-\mathrm{m}$ & $34.0 \mathrm{~d}-\mathrm{k}$ \\
\hline 47 & $18.6 \mathrm{a}-\mathrm{g}$ & $3.37 \mathrm{~h}$ & $59.22 \mathrm{a}-\mathrm{h}$ & 431.3 b-f & 168.4 c-m & 39.1 a-i \\
\hline 49 & $16.9 \mathrm{~d}-\mathrm{g}$ & 3.77 c-h & 55.20 e-h & $524.9 \mathrm{bcd}$ & 202.8 a-f & $38.6 \mathrm{a}-\mathrm{i}$ \\
\hline 50 & $20.2 \mathrm{a}-\mathrm{g}$ & $3.63 \mathrm{e}-\mathrm{h}$ & $58.40 \mathrm{a}-\mathrm{h}$ & 471.8 def & 167.4 c-m & 35.2 b-k \\
\hline 53 & $19.1 \mathrm{a}-\mathrm{g}$ & $3.63 \mathrm{e}-\mathrm{h}$ & $56.20 \mathrm{~d}-\mathrm{h}$ & $415.8 \mathrm{def}$ & $129.5 \mathrm{klm}$ & $31.2 \mathrm{ijk}$ \\
\hline 54 & $21.5 \mathrm{a}-\mathrm{d}$ & $3.57 \mathrm{e}-\mathrm{h}$ & 61.39 a-d & $412.7 \mathrm{def}$ & 147.2 g-m & 35.7 b-j \\
\hline 57 & 21.7 a-d & $3.50 \mathrm{fgh}$ & 54.54 gh & 500.0 b-f & 168.2 c-m & $34.4 \mathrm{c}-\mathrm{k}$ \\
\hline 59 & $22.9 \mathrm{ab}$ & $3.73 \mathrm{c}-\mathrm{h}$ & $56.54 \mathrm{~d}-\mathrm{h}$ & $422.4 \mathrm{c}-\mathrm{f}$ & $149.7 \mathrm{f}-\mathrm{m}$ & 35.4 b-j \\
\hline 60 & $21.2 \mathrm{a}-\mathrm{f}$ & $3.73 \mathrm{c}-\mathrm{h}$ & 59.30 a-h & $452.1 \mathrm{~b}-\mathrm{f}$ & $163.2 \mathrm{~d}-\mathrm{m}$ & $36.1 \mathrm{a}-\mathrm{j}$ \\
\hline 61 & $19.9 \mathrm{a}-\mathrm{g}$ & 3.57 e-h & 57.96 c-h & $412.8 \mathrm{def}$ & $124.0 \mathrm{~m}$ & $31.5 \mathrm{~h}-\mathrm{k}$ \\
\hline 62 & $19.0 \mathrm{a}-\mathrm{g}$ & $3.40 \mathrm{gh}$ & $55.29 \mathrm{e}-\mathrm{h}$ & 417.1 def & 139.7 h-m & $33.4 \mathrm{~d}-\mathrm{k}$ \\
\hline 63 & 21.5 a-d & $4.17 \mathrm{~b}-\mathrm{f}$ & 57.44 c-h & 426.9 c-f & 165.3 c-m & $38.6 \mathrm{a}-\mathrm{i}$ \\
\hline 64 & $20.5 \mathrm{a}-\mathrm{g}$ & $3.63 \mathrm{e}-\mathrm{h}$ & $58.23 \mathrm{~b}-\mathrm{h}$ & 418.7 def & $130.9 \mathrm{j}-\mathrm{m}$ & $31.3 \mathrm{~h}-\mathrm{k}$ \\
\hline 65 & $21.3 \mathrm{a}-\mathrm{f}$ & $4.80 \mathrm{~b}$ & $54.81 \mathrm{fgh}$ & 427.5 c-f & $131.4 \mathrm{j}-\mathrm{m}$ & $30.8 \mathrm{ijk}$ \\
\hline 67 & 17.6 c-g & $3.37 \mathrm{~h}$ & $59.67 \mathrm{a}-\mathrm{g}$ & $462.3 \mathrm{~b}-\mathrm{f}$ & 183.3 b-k & $40.3 \mathrm{a}-\mathrm{g}$ \\
\hline 69 & 20.8 a-g & 3.67 d-h & 55.65 e-h & $554.9 \mathrm{~b}$ & $244.5 \mathrm{a}$ & $44.1 \mathrm{a}$ \\
\hline Elkoca-05 & $21.2 \mathrm{a}-\mathrm{f}$ & 4.27 b-e & $49.63 \mathrm{i}$ & $430.3 \mathrm{c}-\mathrm{f}$ & 178.2 c-l & 41.3 a-e \\
\hline$V K(\%)$ & 12.7 & 9.8 & 4.5 & 12.8 & 13.6 & 11.7 \\
\hline & \multicolumn{6}{|c|}{ F Değerleri } \\
\hline \multirow[t]{2}{*}{ Genotip } & 1.96 & 5.24 & 3.46 & 4.28 & 4.85 & 2.86 \\
\hline & $\mathrm{P}<0.01$ & $\mathrm{P}<0.01$ & $\mathrm{P}<0.01$ & $\mathrm{P}<0.01$ & $\mathrm{P}<0.01$ & $\mathrm{P}<0.01$ \\
\hline
\end{tabular}

(661.8 $\left.\mathrm{g} \mathrm{m}^{-2}\right)$ tespit edilmiş ve bu hatlar ile diğer hatlar ve standart çeşit $\left(430.3 \mathrm{~g} \mathrm{~m}^{-2}\right)$ arasındaki farklar istatistiki olarak çok önemli bulunmuştur. Ayrıca, 69 nolu hat da standart çeşitten önemli seviyede yüksek biyolojik verime (554.9 $\mathrm{g} \mathrm{m}^{-2}$ ) sahip olmuştur. Diğer taraftan, standart çeşitle istatistiki olarak aynı grupta yer almakla birlikte, biyolojik verimi 484.8 ile $545.6 \mathrm{~g} \mathrm{~m}^{-2}$ arasında değişen 12 hat hem standart çeşidin hem de genel ortalamanın önünde yer almıştır (Çizelge 6). Araştırmamızda olduğu gibi, yapılan birçok çalışmada da fasulyede genotipik etkinin bir sonucu olarak, biyolojik verim bakımından önemli varyasyonların bulunduğunu rapor edilmiştir (Bozoğlu, 1995; Ülker ve Ceyhan, 2008; Ceyhan ve ark., 2009).

\subsubsection{Tane verimi}

Tane verimi genotiplere bağlı olarak 121.9 ile $249.5 \mathrm{~g} \mathrm{~m}^{-2}$ arasında olmak üzere çok önemli $(\mathrm{p}<0.01)$ değişim göstermiştir (Çizelge 6). Tane verimi 234.0-244.5 $\mathrm{g} \mathrm{m}^{-2}$ arasında yer alan dört hat (kayıt no 6, 33, 40 ve 69) standart çeşitten $\left(178.2 \mathrm{~g} \mathrm{~m}^{-2}\right)$ önemli seviyede yüksek tane verimine sahip oluşuyla oldukça dikkat çekici bulunmuşlardır. İstatistiki olarak aynı grup içerisinde yer almakla beraber, tane verimi 182.9 ile $217.5 \mathrm{~g} \mathrm{~m}^{-2}$ arasında değişen 11 hat da standart çeşitten daha yüksek tane verimine sahip olmuştur. Tane verimi 121.9 ile $170.0 \mathrm{~g} \mathrm{~m}^{-2}$ arasında değişen 
diğer 25 hat ise hem genel ortalamanın $\left(171.8 \mathrm{~g} \mathrm{~m}^{-2}\right)$ hem de standart çeşidin gerisinde kalmıştır (Çizelge 6). Farklı ekolojik koşullarda yürütülen pek çok araştırma sonucunda da fasulyede tane veriminin çeşit ve genotiplere bağlı olarak önemli değişim gösterdiği rapor edilmiştir (Özçelik ve Gülümser, 1988; Çiftçi ve Yılmaz, 1992; Akdağ ve Şahin, 1994; Bozoğlu, 1995; Düzdemir ve Akdağ, 2001; Ceyhan ve ark., 2009; Varankaya, 2011).

\subsubsection{Hasat indeksi}

Varyans analizi sonuçları, genotipik etkinin hasat indeksi üzerinde çok önemli $(\mathrm{p}<0.01)$ olduğunu göstermiş̧ir (Çizelge 6). Standart çeşitte \% 41.3 olan hasat indeksi, İspir hatlarında \% 26.9 ile \% 44.1 arasında olmak üzere oldukça geniş bir varyasyon göstermiştir. En yüksek hasat indeksi 69 (\% 44.1), 16 (\% 43.0), 40 (\% 42.7) ve 19 nolu hatlarda (\% 41.8) tespit edilmiştir. Bunlara ilaveten, hasat indeksi \% 33.0 ile \% 41.0 arasında değişen 27 hat da standart çeşitle aynı istatistiki grup içerisinde yer almış ve bunlardan 13 tanesi aynı zamanda genel ortalamadan $(\%$ 35.9) daha yüksek hasat indeksi değerine sahip olmuştur. En düşük hasat indeksi ise 42 (\% 26.9) ve 12 nolu hatlarda (\% 28.0) belirlenmiştir (Çizelge 6). Fasulye ile ilgili yapılan diğer çalışmalarda da, hasat indeksi Samsun ekolojik koşullarında \% 26.0-39.0 (Özçelik ve Gülümser, 1988), Tokat ekolojik koşullarında \% 23.9-46.0 (Düzdemir ve Akdağ, 2001) ve Konya ekolojik koşullarında ise \% 21.2-40.1 arasında olmak üzere (Ceyhan ve ark., 2009) genotiplere bağlı olarak önemli değişim göstermiştir.

\subsection{Verim ve verim unsurları arasındaki ilişkiler}

Tane verimi ile incelenen özellikler arasındaki doğrusal ilişkileri gösteren basit korelasyon katsayıları Çizelge 7'de verilmiştir. Korelasyon katsayıları bitkide bakla sayısı, baklada tane sayısı, ilk bakla yüksekliği ve toplam verimin bitki boyu ile ilişkisinin pozitif yönde ve önemli olduğunu göstermiştir. Bitki boyunun ise çiçeklenme $(r=$ $\left.0.49^{* *}\right)$ ve olgunlaşma süresi $\left(\mathrm{r}=0.34^{*}\right)$ ile olumlu ve önemli ilişki içinde olduğu tespit edilmiştir. Diğer taraftan, korelasyon katsayıları incelendiğinde, çiçeklenme süresindeki artışın baklada tane sayısı, ilk bakla yüksekliği ve toplam verimi yükselttiği (sırasıyla $\mathrm{r}=0.36^{*}, \mathrm{r}=0.57^{* *}$ ve $\mathrm{r}=0.31^{*}$ ), yüz tane ağırlığını ise düşürdüğü $\left(\mathrm{r}=-0.38^{*}\right.$ ) anlaşılmaktadır. Yüz tane ağırlığının ayrıca, ilk bakla yüksekliği ve dal sayısı ile de negatif ilişkili olduğu saptanmıştır. Önemli verim unsurları arasında yer alan hasat indeksinin, olumsuz yönde olmak üzere, uzun olgunlaşma süresinden önemli seviyede $\left(\mathrm{r}=-0.64^{* *}\right)$ etkilendiği de korelasyon katsayılarının ortaya koyduğu diğer bir bulgu olmuştur. Benzer ilişkilerin varlığı diğer araştırıcılar tarafından da rapor edilmiştir (Bozoğlu, 1995; Anlarsal ve ark., 2000; Pekşen ve Gülümser, 2005; Çınar, 2015).

Korelasyon analizi, tane veriminin biyolojik verim $\left(\mathrm{r}=0.81^{* *}\right)$ ve hasat indeksi $\left(\mathrm{r}=0.65^{* *}\right)$ ile olumlu ve çok önemli, baklada tane sayısı $(\mathrm{r}=0.31 *)$ ile de olumlu ve önemli ilişkiler gösterdiğini ortaya koymuştur (Çizelge 7 ). Diğer bir ifadeyle, bu özelliklerde meydana gelen artışlar bitki tane veriminde çok önemli veya önemli derecede artışlara neden olmuştur. Bulgularımıza benzer olarak, bazı kuru fasulye genotiplerinin Erzurum ekolojik koşullarına adaptasyonunu araştıran Çınar (2015), fasulyede tane verimine etki eden en önemli unsurların biyolojik verim ve hasat indeksi olduğunu belirlemiştir. Bazı nohut çeşitlerinin Orta Anadolu koşullarına adaptasyonunu araştıran Bıçaksız ve Kayan (2011), tane verimine en önemli doğrudan etkiyi biyolojik veriminin yaptığını ve ayrıca, diğer ögelerin de tane verimine biyolojik verim üzerinden dolaylı etkide bulunduğunu belirlemişlerdir. Wallace et al. (1993), fasulyede tane verimini belirleyen en önemli üç unsurun biyolojik verim, hasat indeksi ve vejetasyon süresi olduğunu bildirmişler ve verim yönünden yapılacak seleksiyonlarda bu üç özellik arasındaki ilişkiyi bilmenin önemli olduğuna vurgu yapmışlardır.

\section{4 İspir yerel fasulye hatlarinin cluster analizine göre sinfflandirllmasl}

Islah ve seleksiyon çalışmalarında üzerinde çalışılan materyalin benzerlik ve farklılıklarının ortaya konulmasında çeşitli istatistik metotlar başarıyla kullanılmaktadır. Bunlar arasında, birden fazla özelliği birlikte analiz etme olanağı sağlayan cluster (kümeleme) analizi, son yıllarda yaygın olarak başarılı bir şekilde kullanılmaktadır (Ceyhan ve ark., 2009; Özçelik ve Sözen, 2009; Kahraman ve ark., 2014). 
Çizelge 7. Tane verimi ile verim unsurları arasındaki ilişkilere ait korelasyon katsayıları

Table 7. Correlation coefficients of the relationship between grain yield and yield components

\begin{tabular}{lllllllllllll}
\hline & & $(1)$ & $(2)$ & $(3)$ & $(4)$ & $(5)$ & $(6)$ & $(7)$ & $(8)$ & (9) & (10) & (11) \\
\hline Çıkış süresi & $(1)$ & 1 & & & & & & & & & & \\
Çiçeklenme süresi & $(2)$ & 0.06 & 1 & & & & & & & & \\
Olgunlaşma süresi & $(3)$ & -0.15 & 0.24 & 1 & & & & & & & & \\
Bitki boyu & $(4)$ & 0.27 & $0.49^{* *}$ & $0.34^{*}$ & 1 & & & & & & & \\
Bitkide bakla sayısı & $(5)$ & 0.17 & 0.21 & -0.05 & $0.38^{*}$ & 1 & & & & & & \\
Baklada tane sayıs1 & $(6)$ & $0.31^{*}$ & $0.36^{*}$ & -0.07 & $0.46^{* *}$ & 0.23 & 1 & & & & & \\
İlk bakla yüksekliği & $(7)$ & 0.12 & $0.57^{* *}$ & 0.14 & $0.62^{* *}$ & 0.05 & $0.39^{*}$ & 1 & & & & \\
Dal sayısı & $(8)$ & 0.22 & 0.21 & -0.19 & -0.04 & 0.17 & 0.24 & 0.16 & 1 & & & \\
Tane verimi & $(9)$ & -0.06 & 0.08 & -0.20 & 0.21 & 0.18 & $0.31^{* *}$ & 0.25 & 0.26 & 1 & & \\
Toplam verim & $(10)$ & -0.22 & $0.31^{*}$ & 0.25 & $0.42^{* *}$ & 0.21 & 0.29 & $0.46^{* *}$ & 0.29 & $081^{* *}$ & 1 & \\
Hasat indeksi & $(11)$ & 0.17 & -0.27 & $-0.64 * *$ & -0.19 & 0.05 & 0.16 & -0.16 & 0.09 & $0.65^{* *}$ & 0.08 & 1 \\
Yüz tane ağırlığı & $(12)$ & -0.27 & $-0.38^{*}$ & 0.043 & -0.23 & -0.02 & -0.22 & $-0.35^{*}$ & $-0.37 *$ & 0.01 & -0.08 & 0.14 \\
\hline
\end{tabular}

*ve ** sirasiyla \% 5 ve \% 1 ihtimal sinırında önemli

$\mathrm{Bu}$ araştırmada da İspir yerel fasulye hatları, varyabilitelerinin saptanması amacıyla, 42 adet özellik bakımından cluster analizine tabi tutulmuş ve dendogram oluşturulmuştur (Şekil 1). Bu özelliklerden 14 tanesi kantitatif, 28 tanesi ise kalitatif özeliklerden oluşmuştur. Cluster analizi sonucunda 5 grubun kümelendiği belirlenmiş ve bunların oluşturduğu grup ve alt gruplar Çizelge 8 ve Şekil 1 'de sunulmuştur.

Grup A: En kalabalık grup olup, toplam genotip sayısı 13 olan üç adet alt gruptan oluşmaktadır. Yaprak özellikleri (yaprak rengi, yaprak pürüzlülüğü, orta yaprakçık büyüklüğü, orta yaprakçık uç şekli) bakımından kendi içerisinde varyasyon göstermektedir. Pek çok çiçek özelliği bakımından ise homojenlik gösteren grup, brakte boyutu orta, brakte rengi yeşil ve kanatçık rengi pembe olan genotipleri içermektedir. Ortalama çiçek uzunluğu bakımından (13.6 mm) Grup B'den sonra ikinci; ortalama çiçek sap uzunluğu $(11.2 \mathrm{~mm})$, ortalama bakla tane sayısı (3.63 adet) ve ilk bakla yüksekliği $(12.9 \mathrm{~cm})$ bakımından ise bütün gruplar içerinde son sırada yer almaktadır. Bu grup, ortalama tane verimi (169.2 $\left.\mathrm{g} \mathrm{m}^{-2}\right)$, biyolojik verim $\left(482.4 \mathrm{~g} \mathrm{~m}^{-2}\right)$ ve hasat indeksi (\% 35.3) değerleri bakımından ise kendine orta siralarda yer bulmuştur.

Grup B: İki alt grupta toplam 7 genotip içermektedir. Yaprak rengi, brakte rengi, bayrak rengi ve kanatçık rengi bakımından diğer hatlardan farklılık gösteren 40, 49 ve 69 nolu hatlar bu grupta bulunmaktadır. Ortalama çiçek uzunluğu $(14.0 \mathrm{~mm})$ bakımından ilk sırada yer almaktadır. Grup D ile beraber en kısa olgunlaşma süresine (ortalama 131.5 gün) sahip hatları içeren grup, Grup C'den sonra en yüksek biyolojik verime (ortalama $532.2 \mathrm{~g} \mathrm{~m}^{-2}$ ) ve tane verimine (ortalama $212.7 \mathrm{~g} \mathrm{~m}^{-2}$ ) sahip oluşuyla dikkati çekmektedir. Grup ayrıca, \% 39.9 hasat indeksi ile ilk sırada yer almaktadır.

Grup C: Tek bir alt grupta 3 genotiple temsil edilmektedir. Bu grup en kısa çiçek boyuna (ortalama $12.0 \mathrm{~mm}$ ) sahip olmasına rağmen, çiçek sap uzunluğu (ortalama $13.3 \mathrm{~mm}$ ) Grup D ile birlikte ilk sırada yer almaktadır. En geçci olan bu grup (ortalama olgunlaşma süresi 138.7 gün), en yüksek bitki boyu (ortalama $103.9 \mathrm{~cm}$ ), baklada tane sayıs1 (ortalama $4.37 \mathrm{~cm}$ ), ilk bakla yüksekliği (ortalama $16.3 \mathrm{~cm}$ ), biyolojik verim $\left(684.0 \mathrm{~g} \mathrm{~m}^{-2}\right.$ ) ve tane verim (ortalama $232.2 \mathrm{~g} \mathrm{~m}^{-2}$ ) değerleri ile gruplar içerisinde ön plana çımaktadır.

Grup D: Bu grupta, standart Elkoca-05 çeşidini de içeren 6 genotip bulunmaktadır. Açık veya orta yeşil ve orta seviyede pürüzlü yapraklara sahip genotiplerin bir kısmı bu grupta kümelenmiştir. Bayrak rengi bakımından ise varyasyon gösteren grup beyaz, pembe ve menekşe bayrak rengine sahip genotipleri bir arada içermektedir. Çiçek sap uzunluğu bakımından Grup $C$ ile beraber ilk sırayı paylaşmaktadır. Grup B ile beraber en kısa olgunlaşma süresine sahip olup, ortalama bitki boyu $(94.9 \mathrm{~cm})$ bakımından ise son sirada yer almaktadır. Grup E'den sonra en düşük biyolojik verime (ortalama $435.3 \mathrm{~g} \mathrm{~m}^{-2}$ ) sahip olmasına rağmen, hasat indeksinin yüksek (ortalama \% 39.5) olması nedeniyle tane verimi bakımından Grup B ve $C$ 'nin ardından üçüncü sırada yer almıştır.

Grup E: Üç alt gruptan oluşan bu grupta toplam 12 genotip kümelenmiştir. Bu gruptaki genotipler çiçek özellikleri yönüyle kendi içerisinde homojenlik gösterirken (brakte boyu orta, brakte rengi yeşil, bayrak ve kanatçık rengi pembe), yaprak özellikleri bakımından varyasyon göstermektedir. Bu grupta daha çok tane verimi, biyolojik 
verimi ve hasat indeksi düşük genotipler kümelenmiş ve dolayısıyla bu üç özellik yönünden (sırasıyla ortalama $136.0 \mathrm{~g} \mathrm{~m}^{-2}, 415.7 \mathrm{~g} \mathrm{~m}^{-2} \mathrm{ve} \%$ 32.9) gruplar içerisinde en son sırada yer almıştır.

Araştırmamızda elde ettiğimiz bu sonuçlar cluster analizinin çok sayıda fasulye hattını incelenen özellikler yönünden başarılı bir şekilde gruplayabildiğini ve bu grupların temel özellikleri dikkate alınarak daha sonra yapılacak islah ve çeşit geliştirme çalışmalarına aktarılacak materyallerin belirlenmesinde başarıyla kullanılabileceğini ortaya koymuştur.

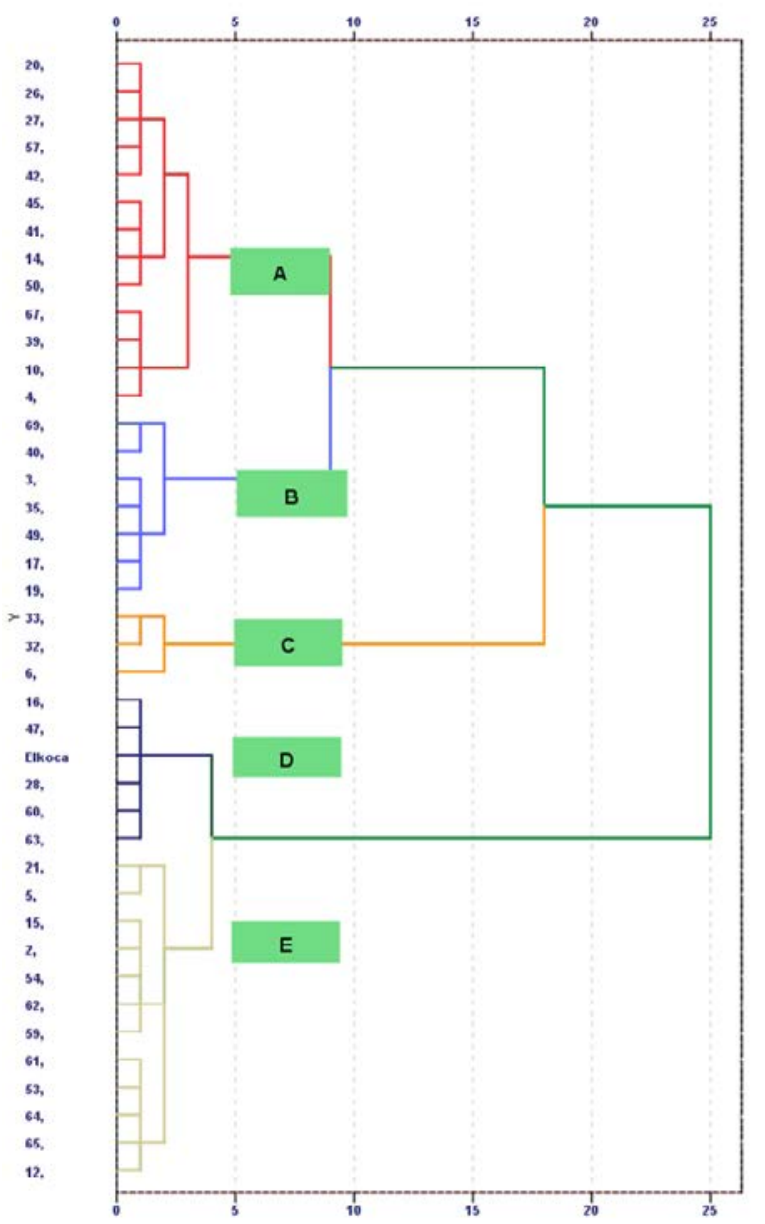

Çizelge 8. Cluster analizi sonucunda belirlenen grup ve alt gruplar

Table 8. Groups and subgroups determined in cluster analysis

\begin{tabular}{llll}
\hline Grup & Alt grup & Genotip & Say1 \\
\hline A & 1 & $20,26,27,57,42$ & 5 \\
& 2 & $45,41,14,50$ & 4 \\
& 3 & $67,39,10,4$ & 4 \\
& Toplam & & $\mathbf{1 3}$ \\
B & 1 & 69,40 & 2 \\
& 2 & $3,35,49,17,19$ & 5 \\
& Toplam & & 7 \\
C & 1 & $33,32,6$ & 3 \\
& Toplam & & 3 \\
D & 1 & 16,47, Elkoca-05, & 6 \\
& & $28,60,63$ & \\
& Toplam & & $\mathbf{6}$ \\
E & 1 & 21,5 & 2 \\
& 2 & $15,2,54,65,59$ & 5 \\
& 3 & $61,53,64,65,12$ & 5 \\
& Toplam & & $\mathbf{1 2}$ \\
Genel toplam & & $\mathbf{4 1}$ \\
\hline
\end{tabular}

Şekil 1. Cluster analizi uygulanan İspir fasulye hatlarına ait dendogram

Figure 1. Dendogram of Ispir bean lines obtained from cluster analysis

Yapılan diğer araştırmalarda da cluster analizinin genotiplerin ayrılmasında başarıyla kullanılabileceğine dair araştırma sonuçları rapor edilmiştir. Çarşamba Ovası'ndan topladıkları bodur taze fasulye popülasyonlarından elde ettikleri saf hatlar arasındaki farklılık ve benzerlikleri ayırma ve kümeleme analizleri yardımıyla ortaya koyan Madakbaş ve ark. (2006), ayırma analizinin kullanılmasıyla benzer olan hatların erken dönemde birbirinden ayırt edilerek kaynak israfının önüne geçilebileceğini belirtmişlerdir. Samsun ekolojik koşullarından topladığg 44 adet barbunya tipindeki fasulye genotipini çok sayıda kantitatif ve kalitatif özellik yönünden cluster analizine tabi tutan Ergün (2005), genotiplerin 6 grup olarak kümelendiğini belirlemiştir. Araştırıcı, incelenen genotiplerin gerek yeni çeşitlerin geliştirilmesinde ve gerekse ileride yapılacak ıslah çalışmalarında kullanılabileceğine vurgu yapmıştır. Artvin'den topladığı beyaz taneli 143 ve renkli taneli 145 fasulye genotipini cluster analizine tabi tutan Sözen (2006), beyaz taneli fasulye genotiplerinin 23, renkli taneli fasulye genotiplerinin ise 26 grup olarak kümelendiğini tespit etmiştir. İncelenen özelliklerde görülen varyasyon ve oluşan farklı gruplar materyalin kuru, taze ve her iki amaca yönelik çeşit geliştirme ve ıslahı çalışmalarında kullanılabilecek kadar zengin olduğunu ortaya koymuştur. Konya ekolojik koşullarında Ceyhan ve ark. (2009) tarafından 16 fasulye genotipinin kullanıldığı ve genotiplerin verim ve verim unsurları bakımından cluster analizine tabi tutulduğu diğer 
bir çalışmada ise genotiplerin iki ana ve her ana grubun da kendi içerisinde çok sayıda alt gruba ayrıldığı saptanmışır. Araştırıcılar, geniş bir varyasyona sahip olan bu fasulye genotiplerinin daha sonraki sslah çalışmalarında rahatlıkla kullanılabileceğini ifade etmiş̧lerdir. Verim ve bazı verim unsurlarını esas alarak 35 kuru fasulye genotipine cluster analizi uygulayan Kahraman ve ark. (2014), genotiplerin üç ana grupta kümelendiğini belirlemişler ve cluster analizinin ümitvar genotiplerin seleksiyonuna yönelik önemli ipuçları vermesi nedeniyle ıslahçılar için kullanışlı olabileceğine vurgu yapmışlardır.

\section{Sonuç}

Sonuç olarak, başta tane verimi olmak üzere incelenen pek çok özellik yönünden üstün özellik gösteren 15 hat (kayıt no 3, 4, 6, 10, 16, 17, 19, 32, 33, 35, 39, 40, 49, 67 ve 69) ile çalışmalara devam edilmesine karar verilmiştir. Seçilen hatlar hem tarla şartlarında verim ve verim unsurları hem de laboratuvarda tane kalite parametreleri yönünden araştırılmaya devam edilecektir. Böylece tarla koşullarında üstün özelliklerini devam ettiren teknolojik özellikleri yüksek hatlar çeşit geliştirme çalışmalarına aktarılacaktır.

\section{Kaynaklar}

Akçin, A., 1974. Erzurum şartlarında yetiştirilen kuru fasulye çeşitlerinde gübreleme, ekim zamanı ve sıra aralığının tane verimine etkisi ile bu çeşitlerin bazı fenolojik, morfolojik ve teknolojik karakterleri üzerine bir araştırma. Atatürk Üniversitesi Ziraat Fakültesi Yayın No: 157, Erzurum.

Akdağ, C., Şahin, M., 1994. Tokat şartlarına uygun kuru fasulye çeşitlerinin belirlenmesi üzerine bir araştırma. Gaziosmanpaşa Üniversitesi Ziraat Fakültesi Dergisi, 11(1): 101-111.

Anlarsal, A.E., Yücel, C., Özveren, D., 2000. Çukurova koşullarında bazı fasulye (Phaseolus vulgaris L.) çeşitlerinde tane verimi ve verimle ilgili özellikler ile bu özellikler arası ilişkilerin saptanması. Turkish Journal of Agriculture and Forestry, 24: 19-29.

Anonim, 2001. Tarımsal değerleri ölçme denemeleri teknik talimatı. Yemeklik Tane Baklagiller. T.C. Tarım ve Köyişleri Bakanlığı, Koruma ve Kontrol Genel Müdürlüğü, Tohumluk Tescil ve Sertifikasyon Merkezi Müdürlüğü, Ankara.

Bıçaksız, Y., Kayan, N., 2011. Bazı nohut (Cicer arietinum L.) çeşitlerinin Orta Anadolu koşullarına adaptasyonu. Uluslararası Katılımlı I. Ali Numan Kıraç Tarım Kongresi ve Fuarı, 2231-2238, 27-30 Nisan, Eskişehir.

Bozoğlu, H., 1995. Kuru fasulyede (Phaseolus vulgaris L.) bazı tarımsal özelliklerin genotip x çevre interaksiyonu ve kalıtım derecelerinin belirlenmesi üzerine bir araştırma. Doktora Tezi. Ondokuz Mayıs Üniversitesi Fen Bilimleri Enstitüsü, Samsun.

Bozoğlu, H., Sözen, Ö., 2007. Some agronomic properties of the local population of common bean (Phaseolus vulgaris L.) of Artvin province. Turkish Journal of Agriculture and Forestry, 31: 327-334.

Ceyhan, E., Önder, M., Kahraman, A., 2009. Fasulye genotiplerinin bazı tarımsal özelliklerinin belirlenmesi. Selçuk Üniversitesi Selçuk Tarım ve Gıda Bilimleri Dergisi, 23(49): 67-73.

Çınar, T., 2015. Bazı kuru fasulye (Phaseolus vulgaris L.) genotiplerinin Erzurum ekolojik koşullarına adaptasyonu ve tarımsal özellikleri. Yüksek Lisans Tezi. Atatürk Üniversitesi Fen Bilimleri Enstitüsü, Erzurum.

Çiftçi, C.Y., Şehirali, S., 1984. Fasulye (Phaseolus vulgaris L.) çeşitlerinde değişik özelliklerin fenotipik ve genotipik farklılıkların saptanması. Ankara Üniversitesi Fen Bilimleri Enstitüsü Yayın No: TB 4, Ankara.

Çiftçi, V., Yılmaz, N., 1992. Van ekolojik koşullarında verimli fasulye çeşitlerinin belirlenmesi ve verim komponentlerinin tane verimine etkisi. Yüzüncü Y1l Üniversitesi Fen Bilimleri Enstitüsü Dergisi, 1(2): 135-146.

Dumlu, B., 2009. Kuzey Doğu Anadolu Bölgesinden toplanılan 23 Fasulye (Phaseolus vulgaris L.) genotipinin fenolojik ve morfolojik karakterizasyonu. Yüksek Lisans Tezi. Atatürk Üniversitesi Fen Bilimleri Enstitüsü, Erzurum.

Düzdemir, O., Akdağ, C., 2001. Türkiye kuru fasulye (Phaseolus vulguris L.) gen kaynaklarının karakterizasyonu. II: Verim ve diğer bazı özellikler. Gaziosmanpaşa Üniversitesi Ziraat Fakültesi Dergisi, 18(1): 101-105.

Elkoca, E., Kantar, F., 2004. Erzurum ekolojik koşullarına uygun erkenci ve yüksek verimli kuru fasulye (Phaseolus vulgaris L.) genotiplerinin belirlenmesi. Atatürk Üniversitesi Ziraat Fakültesi Dergisi, 35(3-4): 137-142.

Ergün, A., 2005. Samsun ilindeki barbunya fasulye gen kaynaklarının karakterizasyonu ve morfolojik varyabilitesinin belirlenmesi üzerine bir araştırma. Yüksek Lisans Tezi. Ondokuz Mayıs Üniversitesi Fen Bilimleri Enstitüsü, Samsun.

Kahraman, A., Önder, M., Ceyhan, E., 2014. Cluster analysis in common bean genotypes (Phaseolus vulgaris L.). Turkish Journal of Agricultural and Natural Sciences, Special Issue 1: 1030-1035.

Kantar, F., Elkoca, E., 2001. Bazı fasulye (Phaseolus vulgaris L.) çeşitlerinin kardinal ve toplam sicaklık isteklerinin belirlenmesi. Türkiye 4. Tarla Bitkileri Kongresi, Cilt I Tahıllar ve Yemeklik Tane Baklagiller, 371375, 17-21 Eylül 2001, Tekirdağ. 
Kantar, F., Elkoca, E., Eken, C., Dönmez, M.F., 2010. Kuzey Doğu Anadolu Bölgesi ve Çoruh Vadisi'nde yetiştirilen kuru fasulye gen kaynaklarının toplanması ve değerlendirilmesi. TÜBİTAK TOVAG 1070400 nolu Proje Sonuç Raporu, Ankara.

Madakbaş, S.Y., Özçelik, H., Ergin, M., 2006. Çarşamba Ovası'nda bodur taze fasulye populasyonlarından belirlenmiş olan hatlar arasındaki farklılıkların belirlenmesi. Harran Üniversitesi Ziraat Fakültesi Dergisi, 10(3/4): 71-77.

Mohammed, H.A, Clark, J.A., Ong, C.K., 1988. Genotypic differences in the temperature responses of tropical crops. I. Germination characteristics of groundnut (Arachis hypogea L.) and pearl millet (Pennisetum typhoides S. \& H.). Journal of Experimental Botany, 39: 1121-1128.

Önder, M., Şentürk, D., 1996. Ekim zamanlarının bodur kuru fasulye çeşitlerinde dane ve protein verimi ile verim unsurlarına etkisi. Selçuk Üniversitesi Ziraat Fakültesi Dergisi, 10(3): 7-18.

Özçelik, H., Gülümser, A., 1988. Bazı bodur fasulye (P. vulgaris L.) çeşitlerinde verim ve bazı verim öğeleri üzerine bir araştırma. Ondokuz Mayıs Üniversitesi Ziraat Fakültesi Dergisi, 3(1): 99-108.

Özçelik, H., Sözen, Ö., 2009. Kelkit Vadisi yerel fasulye (Phaseolus vulgaris L.) populasyonlarının toplanması, karakterizasyonu, morfolojik ve agronomik değişkenliklerin belirlenmesi. TÜBİTAK TOVAG 1080013 nolu Proje Sonuç Raporu, Ankara.

Pekşen, E., Gülümser, A., 2005. Bazı fasulye (Phaseolus vulgaris L.) genotiplerinde verim ve verim unsurları arasındaki ilişkiler ve path analizi. Ondokuz Mayıs Üniversitesi Ziraat Fakültesi Dergisi, 20(3): 82-87.

Sözen, Ö., 2006. Artvin ili yerel fasulye (Phaseolus vulgaris L.) populasyonlarının toplanması, tanımlanması ve morfolojik varyabilitesinin belirlenmesi. Yüksek Lisans Tezi. Ondokuz Mayıs Üniversitesi Fen Bilimleri Enstitüsü, Samsun.

Şehirali, S., Özgen, M., 2006. Bitki 1slahı. Ankara Üniversitesi Ziraat Fakültesi Yayınları No: 1553, Üçüncü Bask1, Ankara.

Ustaoğlu, Y.N., 2008. Tescilli kuru fasulye (Phaseolus vulgaris L.) çeşitlerinde çeşitli fenolojik dönemler için toplam sıcaklık isteklerinin belirlenmesi. Yüksek Lisans Tezi. Atatürk Üniversitesi Fen Bilimleri Enstitüsü, Erzurum.

Ülker, M., Ceyhan, E., 2008. Orta Anadolu ekolojik şartlarında yetiştirilen fasulye (Phaseolus vulgaris L.) genotiplerinin bazı tarımsal özelliklerinin belirlenmesi. Selçuk Üniversitesi Ziraat Fakültesi Dergisi, 22(46): 7789.

Varankaya, S., 2011. Yozgat ekolojik şartlarında yetiştirilen fasulye (Phaseolus vulgaris L.) genotiplerinin bazı tarımsal özelliklerinin belirlenmesi. Yüksek Lisans Tezi. Selçuk Üniversitesi Fen Bilimleri Enstitüsü, Konya.

Wagenvoort, W.A., Bierhuizen, J.F., 1977. Some aspects of seed germination in vegetables. II. The effect of temperature fluctuation, depth of sowing, seed size and cultivar, on heat sum and minimum temperature for germination. Scientia Horticulturae, 6(4): 259-270.

Wallace, D.H., Baudoin J.P., Beaver, J.S., Coyne, D.P., Halseth, D.E., Masaya, P.N., Munger, H.M., Myers, J.R., Silbernagel, M., Yourstone, K.S., Zobel, R.W., 1993. Improving efficiency of breeding for higher crop yield. Theoretical and Applied Genetics, 86(1): 27-40. 